Layout and cover design: Oliver Kleinschmidt, Berlin

Editor: Ria Stein, Berlin

Translation from German (texts by Hofmann, Baumann

and Niederstätter, Hübner): Margot Stringer, Nieuil

Cover: Zürich International School, Galli \& Rudolf

Photographer: Hannes Henz, Zürich

Lithography: Licht \& Tiefe, Berlin

Printing: Kösel, Altusried

Library of Congress Cataloging-in-Publication data

A CIP catalog record for this book has been applied for at the Library of Congress.

Bibliographic information published by the German National Library

The German National Library lists this publication in the Deutsche Nationalbibliografie;

detailed bibliographic data are available on the Internet at http://dnb.dnb.de.

This work is subject to copyright. All rights are reserved, whether the whole or part of the material is concerned, specifically the rights of translation, reprinting, re-use of illustrations, recitation, broadcasting, reproduction on microfilms or in other ways, and storage in databases. For any kind of use, permission of the copyright owner must be obtained.

This publication is also available as an e-book pdf (ISBN 978-3-03821-481-6),

an EPUB (ISBN 978-3-03821-670-4) and in a German language edition (ISBN 978-3-03821-637-7).

First edition 2007 (hardcover) and 2008 (softcover)

Second and revised edition 2015

(C) 2015 Birkhäuser Verlag GmbH, Base

P.O. Box 44, 4009 Basel, Switzerland

Part of Walter de Gruyter GmbH, Berlin/Munich/Boston

Printed on acid-free paper produced from chlorine-free pulp. TCF $\infty$

Printed in Germany

ISBN 978-3-03821-636-0

www.birkhauser.com

98765432 
A DESIGN MANUAL

\title{
Schools and Kindergartens
}

\author{
Mark Dudek \\ Second and Revised Edition
}

\author{
CONTRIBUTIONS BY \\ Dorothea Baumann \\ Mohamed Boubekri \\ Susan Herrington \\ Susanne Hofmann \\ Peter Hübner \\ Pamela Loeffelman \\ Heather Marsden \\ Christina Niederstätter
}



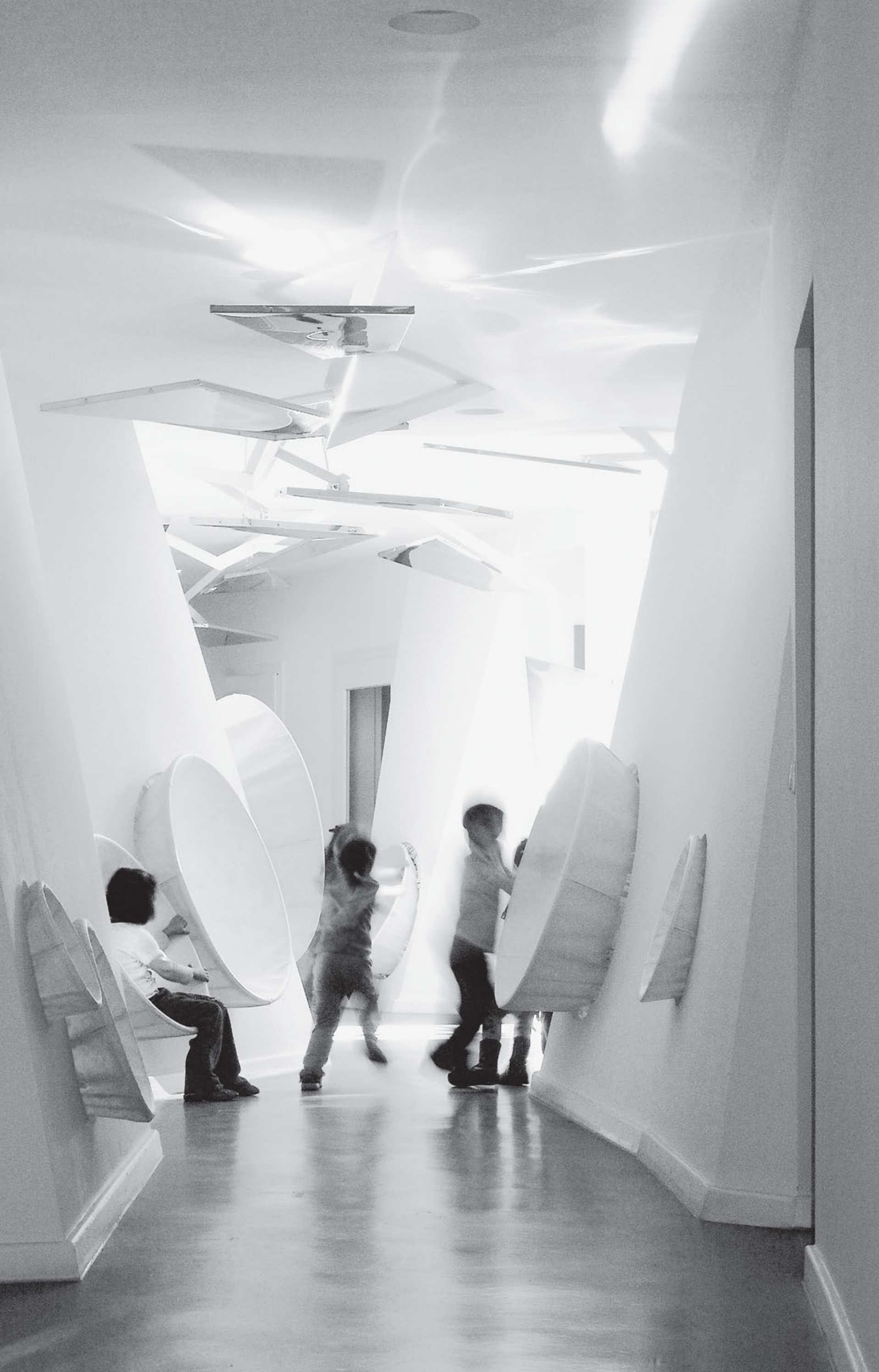